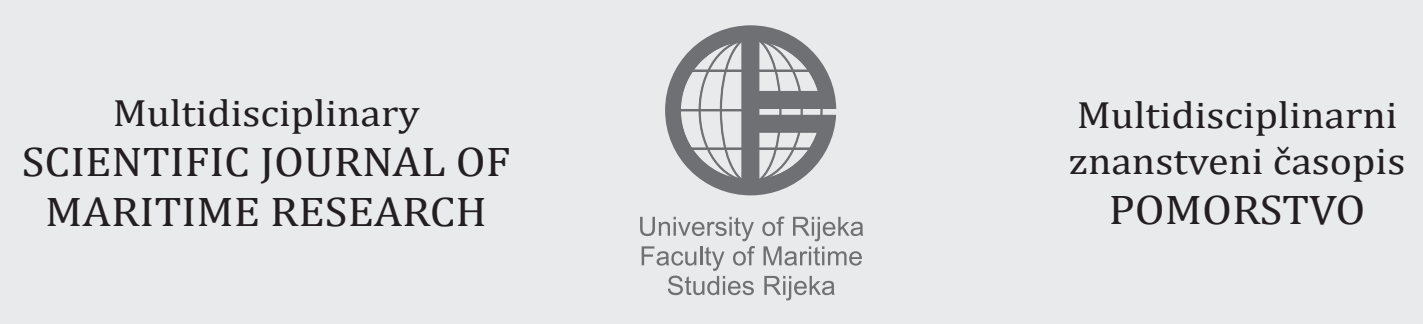

https://doi.org/10.31217/p.32.2.2

\title{
Occupancy Tax Within Tax Models of Nautical Tourism in the Mediterranean
}

\author{
Luka Vukić, Pero Vidan, Eli Marušić \\ University of Split, Faculty of Maritime Studies, Ruđera Boškovića 37, 21000 Split, Croatia, e-mail: luka.vukic@pfst.hr
}

\begin{abstract}
The existing tax models in nautical tourism, different for an individual country, contain various additional taxes already analyzed in scientific researches, while the characteristics and impacts of occupancy tax have been left neglected. The aim of the paper is to examine the impact of occupancy tax on the competitiveness of the price policy in nautical tourism within the Mediterranean countries, by performing the comparative analysis of tax models between the European Union member states and other Mediterranean countries. The results obtained have shown different and hardly comparable tax models, determined by the strategic orientation of the individual country in nautical tourism. The charges of the representatives of two target groups, the occupancy tax prices in Montenegro and similar models in Croatia and Greece have been compared, where the research findings indicated Montenegro as more competitive than the two other EU countries in all categories of the analysis. The obtained results have neglected other destinations comparative advantages mainly favorable to the EU countries having excellent development perspectives. The small scale participation of the occupancy tax in the overall tax model should not allow long-term outflow of the users in the European Union's nautical tourism due to short-term revenue growth. The obtained results have neglected other destinations comparative advantages mainly favorable to the EU countries, having excellent development perspectives.
\end{abstract}

\section{ARTICLE INFO}

Preliminary communication

Received 25 October 2018

Accepted 13 November 2018

Key words:

Occupancy tax

Nautical tourism

Competitiveness

The Mediterranean

\section{Introduction}

The paper aims at presenting the impact of the European Union (EU) member states taxation models examining the competitiveness factor in the Mediterranean by performing the comparison with the non-European Union countries primarily related to the occupancy tax in nautical tourism. The occupancy tax is a form of additional levy participating in the overall price of the service in nautical tourism and typically charged per person and realized overnight stay in various types of tourist accommodations (European Commission, 2017b). Some destinations have introduced a form of tourist tax which has evolved as a significant source of revenue for the local community (Aguiló, 2003) or a mechanism for compensating the negative environmental implications created by tourism activities (do Valle et al., 2012). The balance between the increase in competitiveness on the market and the implementation of additional taxes is considered essential for the sustainable development of the prosperous tourism segment. As a subsector of coastal and maritime tourism, the influence of nautical tourism in the European
Union is reflected in the yearly revenue of 28 billion euros, generating 234,000 jobs (European Commission, 2017c). The nautical tourism term is accompanied by the terminological variations and confusion (Horak, et al., 2006) comprising both yachting, boating, sailing and recreational boating and fishing which are often considered synonyms (Mikulić et al., 2012), given the fact that the term nautical tourism is still not sufficiently defined by the European Union or the United Nations' World Tourism Organization (UNWTO) (Moreno and Otamendi, 2017; Luković, 2007). The authors have used the term nautical tourism for a category of higher rank encompassing the other specific subcategories as the activities of users with boats and yachts on and by water (Jovanović et al., 2016), and in that form has been used in the paper to facilitate the understanding. The enormous potential of this prosperous sector has been recognized by the European Commission in the guidelines of Blue Growth Strategy and the European Strategy for more Growth and Jobs in Coastal and Maritime Tourism supporting the sustainable growth and focusing on the skills, innovation, safety and environmental protection 
(European Commission, 2012; European Commission, 2017a). The plans and strategies are aiming to increase the destination competitiveness and capitalize the growing and prosperous industry. Nautical tourism stimulates economic development and creates a multiplicative effect on other business segments connecting them horizontally and vertically, especially important for the undeveloped or slowly developing regions (Luković et al., 2013). The nautical tourism market, along with the ports in this type of industry, is evolving in the Mediterranean, showing an upward trend on the global scale (Kovačić et al., 2015). The most prominent destinations of nautical tourism in Europe are situated along the Mediterranean coast (European Commission, 2017b) generating approximately half of the sectors' economic output and employment (European Commission, 2017a).

\section{Owerview of the Previous Research}

A limited research on the importance of European occupancy tax has been found in academic literature (European Commission, 2017b), even less explicitly related to occupancy tax in nautical tourism or complementary areas like yachting, boating, recreational boating and crafts or sailing. The majority of the data has been taken from the national legislation of individual countries and their tax policy on occupancy tax in nautical tourism as in the case of Croatia, Montenegro, Slovenia, Italy, Spain, France and Greece, while the global databases have been used for the analysis of other countries primarily as for the lack of data. As in the case of nautical tourism nomenclature diversity the occupancy tax term retrieved from the research performed by the European Commission occurred in diverse forms particularly as tourist tax, accommodation tax, sojourn tax, and others. The occupancy tax has been explained in detail as a segment of the general taxation policy in the document provided by the European Commission (2017), determining the impact of taxes on the competitiveness of European tourism without directly referring to nautical tourism. Moreno and Otamendi (2017) gave the overview of the tax regime applied to nautical tourism in Spain and the Balearic Islands, indicating high rates and levies on users, especially in the charter industry making the destination less competitive than other European destinations situated in the Mediterranean. The research of Vukić et al. (2018) examined the competitiveness of the Croatian sojourn tax, comparing it with the nautical tourism cruising tax in Greece. The paper has presented the foundation of the analysis of occupancy tax in nautical tourism from a price competitiveness perspective. Aguiló et al. (2005) estimated the elasticity of the accommodation tax on the Balearic Islands while do Valle et al. (2012) examined the impact of the accommodation tax utilized for environmental protection in Algarve, a Portuguese tourist destination. Gago et al. (2009) discussed the application of general and specific forms of levies when performing tourist activities, justify- ing them with the environmental and economic benefits to the economy of Spain. The research was performed by the analysis of the tourist tax having similar characteristics as the occupancy tax in nautical tourism. All the cited authors dealt with the analysis of stationary tourist rather than of the nautical tourism users. A great number of scientific papers have been found related to the analysis of the Croatian nautical tourism of almost every segment of the business orientation. Baldigara and Mamula (2012) provided the list of legal acts related to tourism, mentioning also the obligation to compensate the sojourn tax on accommodation services while Bratić et al. (2012) studied the competitiveness of Croatian tax system and its influence on the development of the tourism sector. None of the authors discussed the taxation policy of the occupancy tax in nautical tourism as a singular indicator of competitiveness. Diakomihalis and Lagos (2008) studied the impact of yachting on macroeconomic values of the Greek economy, presenting the overall benefits of the industry without the specific analysis of the occupancy tax.

\section{Nautical Tourism Occupancy Tax in the Mediterranean}

Occupancy tax in nautical tourism is, relatively, modestly represented in European fiscal practice. Starting from different positions, economic development, tradition, and experiences, the interpretation and application of this tax in the Mediterranean countries differ from those in the EU and non-EU members, but also among the EU countries as well.

\subsection{An Overview of Nautical Tourism Occupancy Tax}

A tax system is often considered as a factor of competitiveness influencing the development of the tourism sector (Bratić et al., 2012). Taxes are an important part of the national revenue used for financing the overall product and service as well as investments in infrastructure (European Commission, 2017b). The British Tourist Authority (1998) indicated that sensitivity of the increase and the reduction of the tax rate had repercussions on the service user when choosing a destination of interest. The aim is to strengthen the benefits and its contribution to the macro-regional and micro-regional tourism revenue and economy in general, with a special attention to the sensitive aspects of nautical tourism related to environmental protection, sustainable development, socio-cultural aspects and others. The implementation of a fair and optimal tax system, stimulating the users in the industry should also be considered when determining the range of tax prices. Lipton (1999) discussed if the extremely high taxes influence the boaters selection of the destination and the necessary improvement in the already provided services. Increasing and introducing the additional levies in the tourism sector can lead to negative repercussions on the destinations price competitiveness (European Commission 2017b). The re- 
Table 1 Overview of the Occupancy Tax Model in the Mediterranean Countries (EU and non-EU)

\begin{tabular}{|c|c|c|}
\hline COUNTRY & $\begin{array}{c}\text { OCCUPANCY TAX } \\
\text { IN NAUTICAL TOURISM }\end{array}$ & $\begin{array}{c}\text { CHARACTERISTICS OF OTHER LEVIES ON BOAT } \\
\text { AND YACHT OWNERS AND USERS }\end{array}$ \\
\hline \multicolumn{3}{|c|}{ EU COUNTRIES } \\
\hline Croatia & sojourn tax & ownership-based tax (abolished) \\
\hline Slovenia & tourist tax & $\begin{array}{c}\text { high taxes on possession and use of boats and yachts } \\
\text { in nautical tourism (matriculation tax) }\end{array}$ \\
\hline Italy & $/$ & $\begin{array}{c}\text { high value added tax (VAT) on fuel and insurance } \\
\text { taxes for the crew }\end{array}$ \\
\hline Spain & sojourn tax \\
\hline France & cruising tax (not yet in full application) & \\
\hline Greece & \multicolumn{2}{|c|}{ NON-EU COUNTRIES } \\
\hline Montenegro & sojourn tax & competitive tax rates \\
\hline Turkey & $/$ & high taxes and VAT \\
\hline Israel & $/$ & stimulating tariffs \\
\hline Egypt & $/$ &
\end{tabular}

search performed by the European Commission (2017b) pointed out the importance of supporting regulatory environment when intending to increase the growing market segment, mainly related to tourism, where taxation represents an essential part in achieving the prescribed goals. The research was made upon 28 European Union member states analyzing the main tourism-related taxes, fees, and levies where occupancy tax represents a charge paid on short-term residences in diverse accommodation. The model of occupancy tax is most frequently applied per person using on the per night basis. It is important to note the small range of participation of the occupancy tax in the overall price of accommodation, which is often unfairly neglected given its sensitivity especially in the terms of a drastically increase in the levy upon users. Similar models of an occupancy tax in nautical tourism were implemented in various forms by most of the countries throughout the Mediterranean. These taxes were mainly the reaction of individual governments on the global financial crisis prescribing the measures to increase the duties and taxes on the users of boats and yachts and their owners, enabling the influx of additional income. As the main competitors in nautical tourism are situated in the Mediterranean, each individual occupancy tax model was presented to compare and determine the competitiveness among EU and non-EU countries. The overview of the occupancy tax models in the Mediterranean is shown in Table 1.

\subsection{Nautical Tourism Occupancy Tax in the Mediterranean EU Countries}

Nautical tourism represents an industry of strategic importance for the Croatian national economy and one of the fastest growing segments of tourism (Vukić et al., 2018). Baldigara and Mamula 2012 indicated the existence of Sojourn tax Act, a legal act interconnected with the legal framework of Croatian tourism, which prescribed the obligation of compensating the sojourn tax. It is a form of occupancy tax prescribed for boat owners and their guests staying and sleeping on board their crafts, paying the lump sum rate combing two variables, the craft length and duration of stay. All crafts longer than 5 meters with built-in beds used for vacation, recreation and cruising, excluding a nautical tourism craft, used in commercial purposes for vacation and recreation, and a craft for multi-day cruising in which nautical tourism services are provided (charter, cruising), charged on the realized overnight stay, are obligated to pay the sojourn tax (Croatian Parliament, 2008). The sojourn tax revenue represents an income of the tourist boards on the national, regional and local level used to promote Croatian tourism and to improve the conditions for tourists to stay in a tourist resort. The research of Vukić et al. (2018) demonstrated the drastically increase in the sojourn tax prices for the year 2018 in the segment of nautical tourism, resulting in the potential departure of the users in this industry, especially if imposing additional taxes is not accompanied by the improvement of service and consumer's value for money. The sensitivity of the increase in the overall price and, proportionally, in the tax, has an impact on the consumer's behaviour, having the potential to reduce the destination competitiveness.

The legal framework of the Republic of Slovenia prescribes the payment obligation of the tourist tax for boat and yachts owners as the annual flat rate (lump sum) according to the craft length multiplied by the number and value of the point, determined by the Government of Slovenia, which for January 2015 amounted to $0.115 €$ per point (Municipality of Piran, 2018). When performing the comparison of Slovenia with other countries in the Mediterranean, the shorter coastline and competitive prices should be assumed.

In 2011, the Italian government introduced the berthing tax on yachts implied to Italian and foreignowned yachts over 10 meters in length berthing in Italian ports, navigating or mooring at anchor in Italian waters (Lorenzon and Coles, 2012). The berthing tax was calcu- 
lated and payable based on the length of the yacht and multiplied by the prescribed amount of charge on an annual basis. After the drastic reduction in the flow of foreign yachts in Italian marinas that sailed off to the foreign shores (Nigro and Nigro, 2014), the Italian Parliament amended the berthing tax and implemented the new ownership based tax on yachts implied only to Italian owned yachts with a minimum length of 10 meters, excluding all foreign-owned yachts from paying the tax. This modified tax was also charged as an annual charge according to the craft length. This taxation model of an ownership-based tax was changed again a year later with the Ordinance entitled "Decreto del fare", eliminating the tax for crafts of a length below 14 meters, while reducing the previous tax amounts on yachts from 14.01 meter to 20 meters by $50 \%$ (Puopolo, 2012; 2014). The repercussions of the implementation of additional taxes were evident in the results of the Nautical Tourism Report in 2013, the annual publication which analyses the nautical tourism sector in Italy, where business indicators suffered a drastic decrease. The negative trend was especially significant in the categories of annual berthing contracts which recorded a $26 \%$ decrease, while a $34 \%$ decrease was registered for berthing in Italian ports in transit, 39\% less revenues for publicowned berths, $56 \%$ less for spending at the destination and a $21 \%$ registered loss of the turnover in the charter sector which had an direct impact on more than 10,000 jobs in nautical tourism (Osservatorio Nautico Nazionale, 2013). Moreover, it was estimated that 40,000 users of nautical tourism, discouraged by new taxes, departed from Italy in the period from 2011 to 2013 (Osservatorio Nautico Nazionale, 2016). The ownership based tax was finally abolished in 2015 when the nautical market recovery was immediately apparent recording the increase in almost all business segments, however, still below the trends registered before the global financial crisis and the implementation of additional duties (UCINA, 2016).

According to Luković et al. (2013), nautical tourism is an important segment of the economy of Spain having developed one of the most dominant and best models of sustainable development of coastal and tourist destinations. Besides the global economic crisis, yachting has increased in Spain in the last years evolving as the strategic sector for the Spanish economy (Mestre Abogados, 2015). Moreno and Otamendi (2017) emphasized high taxes on the possession and use of recreational boats in Spain's nautical tourism having rigid bureaucratic procedures. Besides the $21 \%$ of the VAT, nautical tax for navigation assistance, the "T-5" rate for recreational and sports boats and $4 \%$ of tax on capital transfers, Spain introduced a special tax on certain means of transport known as "Matriculation tax" as the only country applying the state tax. Levied at the rate of $12 \%$ on the yacht's value, the matriculation tax refers to all privately owned yachts of 8 meters or more in length which are used in Spanish territorial waters, registered in Spain by a Spanish resident or by a holder of a resident permit in Spain (Lorenzon and Coles, 2012). The amendments from the year 2013 prescribed by Law 38/92 on
Special Tax which regulates the Tax on Certain Means of Transports, determined the exemption of the tax on yachts over 15 meters in length (LOA) stimulating the chartering market of the superyacht category to the interested entrepreneurs (Spanish Law, 2012). However, if the yacht is owned or used by the non-Spanish resident in Spanish waters and not registered in Spain, there is no liability to the matriculation tax (Lorenzon and Coles, 2012). Regarding the Spanish tax and legal rules in force, the differentiated processes of additional tax applications in tourism should be emphasized among Spanish regions causing a large level of uncertainty.

The literature related to the French sojourn tax in nautical tourism shows lack of available data, where the gathered data are often inconsistent and incomprehensible. The sojourn tax or "tax de séjour" in French, applicable to all boats and yachts at a berth regardless to their size, was introduced by the Marseille municipal council for the year 2016, prescribing the obligation to compensate the amount of 0.20 euros per day with an available $50 \%$ discount (La Provence, 2017). The equivalent tariff of sojourn tax for owners staying and sleeping on board the crafts was also introduced by the City of Caen (Cote Caen, 2012). The French regulation on yachts prescribed the annual yacht tax levied on pleasure yachts and boats registered in France called "Droit de navigation" (Lorenzon and Coles, 2012), for residents owning or operating a foreign flagged craft over 7 meters long or equipped with an engine over 22 fiscal horsepower (HP) (about 180HP real) (Bateaux, 2017). The amount of this annual tax is calculated on the overall hull length and combined fiscal horsepower of the engine(s), but the French government adjusted the tax in 2012 by increasing the price and creating a model of higher horsepower base while compensating it with a reduction in the length calculation. One of the largest obstacles for the proper development of the French yachting are large taxes upon users in nautical tourism, evident in the VAT on fuel and insurance taxes for the crew. The VAT on yacht fuel sales has amounted to an enormous $20 \%$, so that bunkering is usually avoided in France in comparison to the neighboring countries. The other segment is the amount of the insurance tax for the crew, based on the new requirement for social security payments intended for all non-French seafarers (crew) based in France, where the craft owners are obliged to compensate these levies which increased from 15 to $55 \%$ of their wages. The repercussions were evident in the $30 \%$ decline in the number of arrivals at the Saint Tropez marina and a 40\% decrease at the marina in Toulon (Daily Beast, 2017). There is an intention from the Government to import a new tax on luxury yachts, supercars and precious metals in France's 2018 budget, replacing the French wealth tax, additionally burdening the yachting industry (The Local, 2017).

From the occupancy tax standpoint in nautical tourism, Greece implemented the cruising tax in 2014, representing a new duty for all private and commercial leisure crafts over 7 meters cruising in Greek waters. The duty was incorporated in the Greek Law in 2016 as well as the newly 
amended law, the Law on the Cruising Tax (TEPAI), which was introduced in 2018, but until now the full application of the tax has not yet entered into practice. The aim of this tax was obviously the revitalization of the struggling economy, devastated by the impact of the global financial crisis, and the possibility of the additional revenue from a profitable and prosperous business. Furthermore, the implementation of the similar taxes in the Mediterranean had an impact on the Greek government to maintain competitiveness among countries (Vukić et al., 2018).

\subsection{Nautical Tourism Occupancy Tax in Mediterranean Non-EU Countries}

Montenegro has positioned its nautical tourism as an activity of strategic interest for the national economy. The Government prescribed the obligation to pay residence tax for owners of nautical tourism leisure crafts, boats, and yachts residing in Montenegro in the form of a flat rate (lump sum) according to the crafts length and the tourists' length of stay on board the nautical tourism leisure crafts. The tax is similar to the model used in Croatia (Government of Montenegro, 2016).

As indicated by Luković et al. (2013), the strategic orientation of Turkey is related towards the development of tourism and nautical tourism, especially yachting. Sariisik et al. (2011) stated the high potential of Turkish yachting tourism exploiting the comparative advantages manifested in the long coastline, natural resources and quality of accommodation services. The Turkish marinas created competitive prices in the yachting industry, lower than those in the North-western Mediterranean by $40 \%$ to $60 \%$, and $30 \%$ lower than the Greek marinas and complementary to those prices in the Eastern Adriatic countries (Diakomihalis, 2007). Moreover, there is no VAT for the services of yachting managements in Turkey (Tandogan, 1998). The Turkish government stimulated the domicile yacht owners using foreign national flags to facilitate the change to the Turkish flag in 2009 with numerous measures, like the reduction of Special Consumption Tax (SCT) on yacht sales from $8 \%$ to zero, VAT for the purchase of yachts and all products both imported and locally manufactured from $18 \%$ to $1 \%$ (Inal Law Office, 2017), while increasing the Private Consumption Tax (PCT) to $23 \%$ for the yacht sales in 2017 (Daily Sabah, 2017). The available literature indicates that there are no additional taxes upon owners and their guests on board leisure crafts sailing in Turkish waters for recreational and private purposes, as opposite to commercial activities, making the destination preferable from the user's economic aspect and imposed supplementary charges.

When valorizing the nautical tourism activities in Israel, a lack of available research data is evident, especially when analyzing the taxation model used for nautical tourism, so this should be emphasized for the research. Recreational boating and yachting, a subsegment of nautical tourism, is besides shipping, energy production and fishing, one of the most important marine activities in
Israel (Goffredo and Dubinsky, 2014). The Israeli Ministry of Finance introduced the tax on luxury items, a wealth tax, in 2014 which included airplanes, quad bikes and yachts and other items. It was related to private boat and yacht owners and amounted to $15 \%$ of the value of the craft imported to Israel with the additional $17 \%$ of VAT levied to both Israeli and foreign-flagged crafts (Globes, 2017). A foreign-flagged craft staying in Israel for less than 3 months is exempted by the tax, but after three months is obliged to compensate the tax prescribed by the law in the total amount of $34.55 \%$. From the analysis of the available data, it can be concluded that Israel too does not impose additional levies upon users in nautical tourism.

The additional charges in the taxation systems of some African countries performing nautical tourism activities in the Mediterranean like Morocco, Algeria, Egypt, and Tunis, as well as Lebanon representing the Middle East, were analyzed to demonstrate the price policy directed to the users in nautical tourism. The analysis of occupancy tax prices in developing non-EU countries of this specific segment of tourism was intended to demonstrate discrepancy in comparison with the EU countries. Algeria, Morocco, Cyprus, and Egypt are responsible for $6 \%$ of the total demand for services in the Mediterranean (Diakomihalis, 2007). Only the main characteristics of the nautical tourism tax model, as a result of the shortage of relevant data, were demonstrated for Egypt. The data for other countries were left unavailable. The Government of Egypt is gradually investing in the prosperous nautical tourism in both new nautical tourism ports and accompanying nautical tourist facilities. The demand in nautical tourism in Egypt, comprising yachts and other crafts, has grown in recent years when the Egyptian government reduced the customs duties for all imported yachts and other crafts in 2005 to almost $90 \%$. The trend showed a significant increase in the yacht sales in the later years, particularly when a change in sale tax was also implemented and reduced from $45 \%$ to $5 \%$ (Nautech, 2017). It can be assumed that neither country has imposed additional charges on owners and users of crafts in nautical tourism for accommodation purposes.

Vukić et al. (2018) indicated the existence of tax oasis in the Mediterranean. Malta and Gibraltar have positioned their business orientation to nautical tourism activities offering lower levies of the VAT and lower berth prices drawing the attention for the users in nautical tourism. The demand for services of these two Mediterranean territories can be expected in the future giving the optimization of the users cost as a global discipline and philosophy.

\section{Discussion}

Compared to other taxes, occupancy tax represents a small proportion of the overall levies on users in tourism, but is significant to the consumer when choosing a destination to stay affecting its behaviour. This form of additional tax has a purpose to increase the revenue 
and to compensate the reduced budget deficit. It is often used to invest in the infrastructure and promotion of the destination justifying it with the negative consequences arising with the increased tourist flow and impact on the environment and quality of everyday living (European Commission, 2017b).

The change in the segment of occupancy tax or the implementation of additional levies could lead to the departure of the nautical tourism users, as in the Italian example, but most likely it shall lead to the shorter stay in nautical tourism ports and marinas and possible lower consumption at the destination. The negative consequences would be manifested especially if the increase in tax is not accompanied by the proportional investment in the overall service and product or the users' value of money. The nautical tourism price elasticity in the demand for services is something that policy makers should consider and integrate into the planned activities when determining the destinations strategy. Only a fair and optimal amount of occupancy tax incorporated in the final price of the service can lead to the sustainable development of the prosperous sector, while, simultaneously, concerning for the environmental protection, societal impact and generating economic benefits of a tourist destination (Lapko, 2016). When determining the destination to stay at, the user comprises the natural and climate resources firstly, but the additional levies could lead to a probable change in overall perception and possible preference of the destination.

The overview of the taxation policy in the Mediterranean has demonstrated dissimilarity in the creation of tax models on the users in nautical tourism. The aim has been to analyze and study the competitiveness of occupancy tax, but the analysis has been performed only with those countries having implemented the tax. The current approach on taxing the nautical tourism accommodation activities of some individual EU countries like Italy, France and Spain and the majority of non-EU countries, except Montenegro, has also been presented. The analysis of main nautical tourism EU countries in the Mediterranean has shown several modes of occupancy tax on the users of boats and yachts like in Croatia, Slovenia, Greece and some regions in France, while Italy abolished the controversial ownership tax in 2015. On the other hand, Spain, as one of the countries with the highest levies in nautical tourism, has not implemented the occupancy tax on vessels. The fact that overall levies are already burdening the users in nautical tourism can justify this measure. The countries outside the EU, from the standpoint of additional levies, are faced with the simplified administration especially in the segment of EU tax regime and reduced VAT on fuel. The established nautical tourism countries like Italy, France, and Spain and their comparative natural, cultural, and other advantages in nautical tourism will surely remain the main user's motivation when choosing a destination to stay at. These countries are expected to remain competitive in the Mediterranean while the high taxes, like in the case of France and Spain, could become the main obstacle for the desired expansion and acquisition of additional consumers. Italy, once faced with the extremely high additional taxes is now recovering slowly, gradually restoring the users' trust and stimulating the nautical tourism with lower taxes. This exodus of the users from Italian marinas and nautical tourism ports should serve as an example for price and policy makers in other countries with desired activities and profit in nautical tourism. Concerning Turkey, the autonomy and shift from the EU legislation, high interest in the industry and stimulating taxes and prices are the main advantages for the development of nautical tourism activities. Turkey has been increasingly investing in this prosperous tourism segment evident in the presence of Doğuş Group, one of the leading conglomerates of Turkey, and its marinas in Croatia and Greece. A further market penetration and a rise in the competitiveness of Turkish nautical tourism conducive to tax environment can be expected. Israel has created an opposite approach in nautical tourism increasing the levies on users not capitalizing on the prosperous market. The other countries are expected to create a favourable tax environment in nautical tourism which should expand proportionally with the development of the entire economic system.

When performing the analysis upon four non-EU countries in the Mediterranean and upon other African and Middle East countries where the lack of data occurred, it is evident that only Montenegro charges the users with sojourn tax when using crafts for accommodation in internal and territorial waters. Surely, Montenegro has highly invested in nautical tourism which has become one of the strategic sectors for the national economy, while the other countries are still faced with several obstacles, mainly geopolitical, in the internal or external environment thus affecting the nautical tourism development. When comparing the EU Member States with the countries outside of the EU in the segment of nautical tourism occupancy tax in the Mediterranean, the disproportion of the price policy in the two entities is evident, with Montenegro as an only representative of the non-EU countries having implemented sojourn tax in nautical tourism. Despite it, such constellations affect the acquisition of the competitive advantage over individual EU member states already influenced by the stimulating berth price policy of the countries outside the EU, thus increasing its own nautical tourist flows. The tendency to isolate the input of the taxation model in the research, having the objective to indicate the competitiveness of a small segment of business, should also be emphasized, neglecting the other comparative advantages and disadvantages of individual countries in nautical tourism.

The comparison of occupancy tax prices of the two entities has been taken to analyze the pricing policy of additional levies in nautical tourism. The similarity between Croatia and Greece, in terms of the length of the indented coast and an overall number of boats and yachts in their marinas, and with the Montenegrin similar tax model, a residence tax, gave and enabled a favorable foundation for the selection of variables performed in the analysis. The main objective has been to assess the competitive factor 
of the three countries regarding the occupancy tax with the analysis of individual model prices. As for the position of Slovenia, due to its shorter coast and the incomparable charges, the analysis has been unsuitable and not applicable for the analysis. The preparation of the data required the modification of cruising tax prices in Greece to a specific category of crafts length in order to compare it with the Montenegrin sojourn tax. It has been performed by creating an average price for the specific category of crafts length according to the combination of the individual prices of the crafts length. Regarding the comparison of the Croatian sojourn tax in nautical tourism with an occupancy tax in Montenegro, the existing and prescribed categories of the crafts length have been taken for the comparison regardless of the minor difference which has been insignificant for the research. The aim has been to assess the range of difference in the occupancy tax prices of the EU countries as compared to those prices of the representative country outside the EU, rather than to the absolute values. The comparison has been carried out by combining two variables: the duration of the stay, and the length of the craft. The variable of the duration of stay has been compared regarding the monthly and annual charge, with the selected crafts length varying from 11 to 15 meters, from 16 to 20 meters and over 20 meters in length. Some of the variables of the Croatian and Greek occupancy taxes in nautical tourism have been adjusted to perform the comparison. Furthermore, the premise of the application of cruising tax in Greece has also been taken into analysis. The results obtained are presented in Table 2 .

The results have shown the evident discrepancy between the two territories and legal entities, one outside the EU zone and two countries as constitutional parts of the European Union. While the occupancy tax prices as a monthly charge in nautical tourism are two to eight times higher for the EU Member States, the differences based on the annual charge are astonishingly twelve to almost twenty times higher in Croatia and Greece. The results have shown that Montenegro is more competitive than both Croatia and Greece in all segments taken into this analysis. Moreover, the analysis between the EU countries has shown that Greece is more competitive than Croatia for the monthly charge in all categories of the analyzed crafts length, while Croatia is more competitive in the tax prices based on the annual charge for all categories of the crafts. The difference of small-scale, most to two times, between these two EU countries is something that has been expected for the research findings.

The price policy in nautical tourism depends on numerous conditions in the market taking into account the performance indicators, capacity of ports, attractiveness of the destination, elasticity of supply and demand and other accompanying tourist services, so the price diversity can be anticipated in the various categories of the crafts length and duration of stay. Surely, the comparison of nautical tourism in Croatia and Greece, a two similar countries, with Montenegro is imbued with diversity in various categories of individual comparative advantages, but the drastically dissimilarity in the prices of the EU and nonEU countries is something that one could question when determining the true intention of creating these prices. Having the insight into occupancy tax charges, the question arises whether the Montenegrin price policy and the price policy of other non-EU countries analyzed in this paper, are created as a possibility to utilize the non-EU tax regime and legislation and its competitive advantage in the creation of the unique and stimulating prices of occupancy tax as well as other taxes in the nautical tourism market, while considering also the possibility of dumping occupancy tax prices in order to remain more competitive

Table 2 Comparison of the Residence Tax in Montenegro with the Sojourn Tax in Croatia and Cruising Tax in Greece (Slovenian Tourist Tax Incomparable)

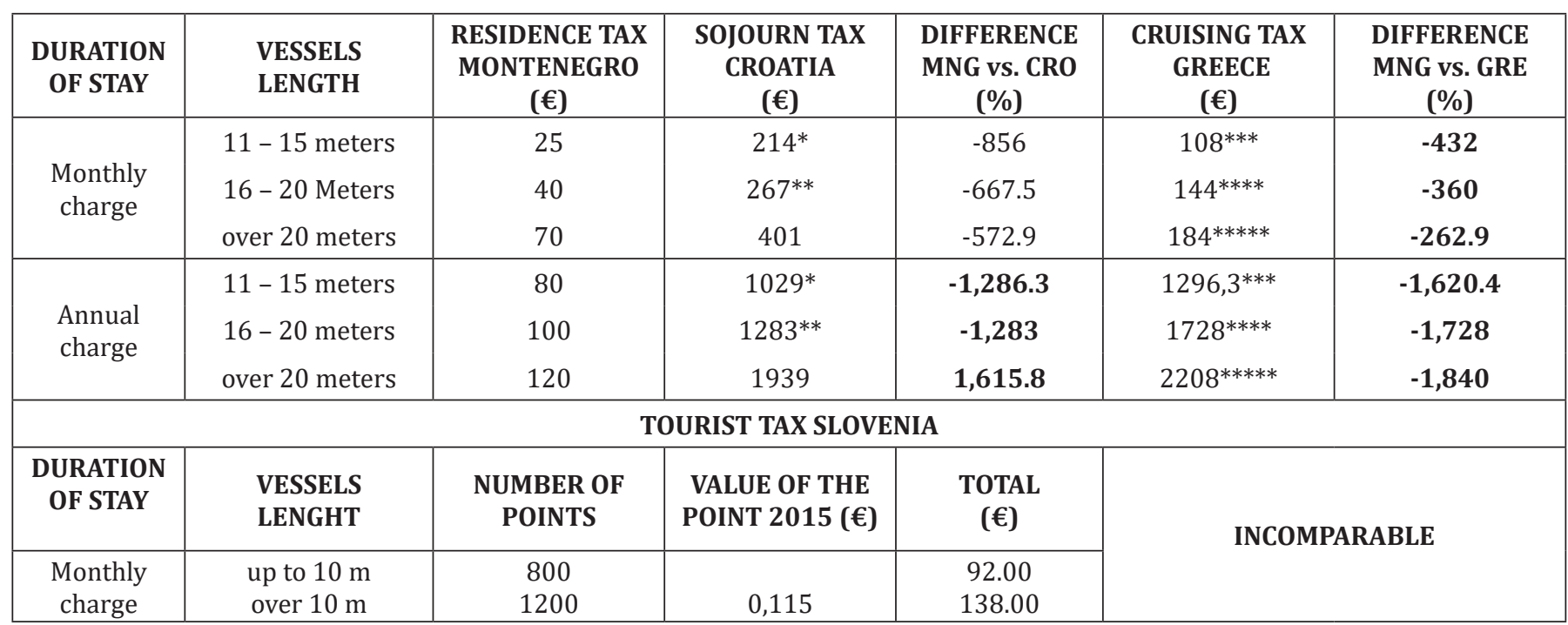

*average price for the category from 12 to 15 meters in length; ** average price for the category from 15 to 20 meters in length; *** average price calculated from the individual prices for crafts of $12,13,14$ and 15 meters in length; **** average price from the individual prices for crafts of 16,17 , 18,19 and 20 meters in length; ${ }^{* * * *}$ average price from the individual prices for crafts of $21,22,23,24$ and 25 meters in length 
and preferably as a destination to stay at. These indications can also be associated with the tax oasis, mentioned in the first paragraph of the paper, and in other segments of nautical tourism, but not at the occupancy tax level. Lowering the tax rates and prices on users, as in the case of Gibraltar and Malta, can result with the increase in the demand for services and consumption, but also in the negative consequences of the denial of the fair and equal competition among other nautical tourism destinations in the Mediterranean, where the price mechanism should correspond, or at least, be similar to other models.

The enormous discrepancy in prices and taxes between the EU and non-EU countries, in favour of the latter, could develop into a potential threat for the future development of nautical tourism and competitiveness in the EU, having in mind the cost optimization as a main policy on the global market. Surely, the favourable natural and climate characteristics of a destination as well as the geopolitical environment and other parameters of a destination should influence on the selection of the country of stay, but the difference in the tax regime could have an impact on the consumer's behaviour (Bratić et al., 2012). The non-EU countries are evolving in the nautical tourism sector ennobling the supply of products and services, so their favorable tax policy could lead to a rise in competitiveness and in the acquisition of an additional market share. The optimization of cost, as a consumer's philosophy and discipline, will become more prominent having a direct impact on the destination competitiveness, promoting the destinations outside the Union as well as in tax oases, like Malta and Gibraltar, offering lower tax rates and increasing the consumption at the destination.

\section{Conclusion}

Occupancy tax in the Mediterranean is a small part of the tax system established in accordance to the efforts of individual countries to attract users to their marinas, but it can also be an indicator of movement on the tourist market. It is clear that a certain tax model in nautical tourism is determined by the role of nautical tourism in the development strategy of an individual country. Tax models in the nautical tourism are very sensitive so that a little imbalance of the model can result in the loss of customers. As other taxes, the occupancy tax should not be the reason for choosing or changing the specific destination. The tax models are different and hard to compare. Only three Mediterranean EU member countries (Croatia, Slovenia, and Greece) and one non-EU country (Montenegro) are marked as comparable due to their occupancy tax model in nautical tourism. Other countries compensate it with other taxes. Generally, the EU member tax models in nautical tourism are uncompetitive in relation to the same or similar in the Mediterranean countries outside the Union as well as in tax oases. The same applies to the occupancy tax among the countries suitable to compare. The small capacities in Montenegro and other Mediterranean non-EU countries marinas, as well as the political situation in the Eastern Mediterranean, correspond to the countries of the Union that have not lost their users so far. In such circumstances, the EU nautical tourism has an excellent development perspective, and the tax policy, including the occupancy tax in nautical tourism, should not allow long-term outflows of customers due to the short-term revenue growth.

\section{References}

[1] Aguiló, E., Riera, A., Rosselló, J. (2005) The short-term price effect of a tourist tax through a dynamic demand model: The case of the Balearic Islands. Tourism Management, 26(3), pp. 359-365. doi: https://10.1016/j.tourman.2003.07.005

[2] Baldigara, T., Mamula, M. (2012) Tourism Statistics in Croatia: Present Status and Future Challenges. In: Korunovski, S., Strezovska, J., Andreeski, C. XI International Conference Service Sector in Terms of Changing Environment. Springer: Procedia - Social and Behavioral Sciences, pp. 53-61.

[3] Bateaux (2017) Available at: https://www.bateaux.com/article/26405/calculer-droit-annuel-de-francisation-de-navigation (05.04.2018)

[4] Bratić, V., Bejaković, P., Devčić A. (2012) Tax System as a Factor of Tourism Competitiveness: The Case of Croatia. Procedia - Social and Behavioral Sciences, 44, pp.250-257. doi: https://doi.org/10.1016/j.sbspro.2012.05.027

[5] British Tourist Authority (1998) The Economic Effects of Changing VAT Rates on the British Tourism and Leisure Industry-Executive Summary. VAT Working Group, Deloitte and Touche.

[6] Cote Caen (2012) Available at: http://www.cotecaen. $\mathrm{fr} / 17509 /$ dans-le-port-de-caen-les-plaisanciers-residentstaxes/ (05.04.2018)

[7] Croatian Parliament (2008) Sojourn Tax Act. Official Gazette 152/08, 59/09 - correction and 30/14, Zagreb, Croatia.

[8] Daily Beast (2017) Available at: https://www.thedailybeast. com/where-did-all-the-superyachts-go (25.03.2018)

[9] Daily Sabah (2017) Available at: https://www.dailysabah. com/business/2017/02/22/limits-to-be-set-for-turkish-citizens-docking-yachts-without-turkish-flags (25.03.2018)

[10] Diakomihalis, M., Lagos, D. (2008) Estimation of the economic impacts of yachting in Greece via the tourism satellite account. Tourism Economics, 14(4), pp. 871-887. doi: https:// doi.org/10.5367/000000008786440139

[11] Diakomihalis, M.N. (2007) Greek Maritime Tourism: Evolution, Structures and Prospects. In: Athanasios A. Pallis (ed.), Research In Transportation Economics Maritime Transport: The Greek Paradigm, Oxford: Elsevier. doi: https://doi. org/10.1016/S0739-8859(07)21013-3

[12] do Valle O.P., Pintassilgo, P., Matias, A., André, F. (2012) Tourist attitudes towards an accommodation tax earmarked for environmental protection: A survey in the Algarve. Tourism Management, 33(6), pp.1408-1416. doi: https://doi. org/10.1016/j.tourman.2012.01.003

[13] European Commission (2012) Blue Growth - opportunities for marine and maritime sustainable growth. Luxembourg: Publications Office of the European Union. Available at: https://ec.europa.eu/maritimeaffairs/sites/maritimeaffairs/ files/docs/publications/blue-growth_en.pdf

[14] European Commission (2017a) Commission Staff Working Document on Nautical Tourism. Luxembourg: Publications 
Office of the European Union. Available at: https://ec.europa. eu/maritimeaffairs/sites/maritimeaffairs/files/swd-2017126_en.pdf

[15] European Commission (2017b) The Impact of Taxes on the Competitiveness of European Tourism. Luxembourg: Publications Office of the European Union. Available at: http://www. europarl.europa.eu/cmsdata/130660/The\%20Impact\%20 of $\% 20$ Taxes $\% 20$ on $\% 20$ the $\% 20$ Competitiveness $\% 20$ of $\% 20$ European\%20tourism.pdf

[16] European Commission (2017c) Assessment of the Impact of Business Development Improvements around Nautical Tourism. Luxembourg: Publications Office of the European Union. Available at: https://publications.europa.eu/en/publicationdetail/-/publication/473c0b82-18f9-11e7-808e-01aa75ed71a1

[17] Gago, A., Labandeira, X., Picos, F., Rodríguez, M. (2009) Specific and general taxation of tourism activities. Evidence from Spain. Tourism Management, 30(3), pp.381-392. doi: https://doi.org/10.1016/j.tourman.2008.08.004

[18] Globes (2017) Available at: http://en.globes.co.il/en/ article-israeli-yacht-owners-appeal-inclusion-in-richtax-1001213346 (25.03.2018)

[19] Goffredo, S., Dubinsky, Z. (2014) The Mediterranean Sea: Its history, and present challenges. Dodrecht: Springer Science Business Media Dordrecht.

[20] Government of Montenegro (2016) Regulation Of The Amount Of Residence Tax For Vessels In Nautical Tourism. Official Gazette of Montenegro number 10.

[21] Horak, S., Marusic, Z., Favro, S. (2006). Competitiveness of Croatian nautical tourism. Tourism in Marine Environments, 3(2), pp. 145-161.

[22] Inal Law Office (2017) Available at: http://www.inal-law. com/EN/Blog-Post-Details/TAX-REDUCTION-IN-THECHANGING-OF-YACHTS\%E2\%80\%99-FLAGS-FROM-FOREIGN-TO-TURKISH-WITHIN-THE-SCOPE-OF-THE-LAWON-THE-AMENDMENT-OF-THE-RETIREMENT-FUNDLAW-AND-CERTAIN-LAWS-AND-STATUTORY-DECRE ES-/09816309004211706887(25.03.2018)

[23] Jovanovic, T., Dragin, A., Armenski, T., Pavic, D., Davidovic, N. (2013) What Demotivates the Tourist? Constraining Factors of Nautical Tourism. Journal of Travel \& Tourism Marketing, 30(8), pp.858-872. doi: https://10.1080/10548408.2013.835679

[24] Kovačić, M., Gračan, D., Jugović, A. (2015) The scenario method of nautical tourism development - A case study of Croatia. Pomorstvo - Scientific Journal of Maritime Research, 29(2), pp. $125-132$.

[25] La Provence(2017) Available at: https://www.laprovence. com/article/faits-divers-justice/4241027/la-taxe-de-sejourqui-fait-tanguer-la-plaisance.html (05.04.2018)

[26] Łapko, A. (2016) The Use of Auxiliary Electric Motors in Boats and Sustainable Development of Nautical Tourism Cost Analysis, the Advantages and Disadvantages of Applied Solutions. Transportation Research Procedia, 16, pp.323328. doi: https://doi.org/10.1016/j.trpro.2016.11.031

[27] Lipton D.W. (1999) Boat Location Choice: The Role of Boating Quality and Excise Taxes. Coastal Management, 27(1), pp.8189. doi: https://doi.org/10.1080/089207599263910

[28] Lorenzon, F., Coles, R. (2012) The Law of Yachts and Yachting. Informa Law from Routledge 1st edition. London, United Kingdom.

[29] Luković, T. (2007). Nautical tourism in Europe, definition and classification. Actaturistica nova, 1(2), pp. 155-167.
[30] Luković, T. et al. (2013) Nautical tourism. CAB International, Oxford.

[31] Mestre Abogados (2015) Yachting developments in Spain. Available at: http://www.mestreabogados.com/pdf/Yachting-developments-in-Spain.pdf (25.03.2018)

[32] Mikulić, J., Krešić, D., Kožić, I. (2015) Critical Factors of the Maritime Yachting Tourism Experience: An ImpactAsymmetry Analysis of Principal Components. Journal of Travel and Tourism Marketing, 32(1), pp.30-41. doi: https://10.1080/10548408.2014.981628

[33] Moreno, M.J., Otamendi, J.F. (2017). Fostering Nautical Tourism in the Balearic Islands. Sustainability, 9(12), pp.1-20. doi:https://10.3390/su9122215

[34] Municipality of Piran, (2018) Novosti na področju registracije nastanitvenih obratov in poročanja $\mathrm{v}$ turizmu, Piran, Slovenia. Available at: http://www.piran.si/index. php?page=static\&item $=598(05.04 .2018)$

[35] Nautech (2017) Available at: http://www.nautechnews. it/2017/10/16/yachting-is-young-egypt/ (05.04.2018)

[36] Nigro, B., Nigro, L. (2014) Formulario del Contenzioso Tributario: IV edizione aggiornata con la Legge di Stabilita peri l 2014. Maggioli Editore, Italy.

[37] Osservatorio Nautico Nazionale (2013) Rapporto sul turismo nautico, Genova: ONN.

[38] Osservatorio Nautico Nazionale (2016) Portualita Nautica. Available at: http://slideplayer.it/slide/9907880/ (21.05.2018)

[39] Puopolo, G. (2012) Captains' Forum: latest developments on Italian Tax and Legal issues. Yacht Club de Monaco - April 19, 2012. Available at: http://www.pglegal.it/attachment. ashx?uid=b67f256a-29d0-4331-9528-4c71c03c4b6b

[40] Puopolo, G. (2014), The Italian Yachting Industry: a brief overview of the market and the state of play in the tax and the law. Yacht Club de Monaco 2014. Available at: http:// www.pglegal.it/attachment.ashx?uid=217965bb-e2c2-4672a640-1b2075edbc51

[41] Sariisik, M., Turkay, O., Akova, O. (2011) How to manage yacht tourism in Turkey: A swot analysis and related strategies. Procedia Social and Behavioral Sciences 24, pp.1014-1025. doi: https://doi.org/10.1016/j.sbspro.2011.09.041

[42] Spanish Law (2012) Ley 38/1992, de 28 de diciembre, de Impuestos Especiales: Última modificación: 28 de diciembre de 2012 - Texto Consolidado. Instituto Europeo de Asesoría Fiscal, Biblioteca De Legislación. Available at: www.ineaf.es

[43] Tandogan, U.V. (1998) Dünya Turizm Talebi Eğilimleri Işığında Türkiye'ye Yönelik Yat Turizm Talebinin Değerlendirilmesi. Balıkesir Üniversitesi Sosyal Bilimler Enstitüsü Dergisi, 1(1), pp. 145-155.

[44] The Local (2017) Available at: https://www.thelocal. $\mathrm{fr} / 20170930$ /got-a-yacht-proposed-french-tax-breakmakes-waves (21.05.2018)

[45] UCINA (2015) La nautica in cifre. Analisi del mercato perl'anno 2015, Fondazione Edison. Available at: http:// liguria.bizjournal.it/wp-content/uploads/2016/09/D_-_La_ Nautica_in_Cifre_-_Analisi_del_mercato_per_lanno_2015_-DIGITAL.pdf

[46] Vukić, L., Vidan, P., Marušić, E. (2018) Comparative analysis of Croatian sojourn tax in nautical tourism with corresponding tax in Greece. $5^{\text {th }}$ International Scientific Conference: Trends in Development of Tourism and Hospitality, October 1112.2018, Kotor, Faculty of Tourism and Hotel Management, Montenegro. 